\title{
Practices of Local Social Forums: The Building of Collective Action Repertoires
}

\section{Research in Social Movement Conflict and Change}

\section{(Note: This article is (c) Emerald Group Publishing and permission has been granted for this version to appear here (http://hdll.handle.net/1866/12268). Emerald does not grant permission for this article to be further copied/distributed or hosted elsewhere without the express permission from Emerald Group Publishing Limited)}

In October 2011, four thousand people spent three days in a small village of 400 inhabitants in the Bas-du-Fleuve region in Quebec, Canada, dividing their time between participative workshops, social gatherings and artistic performances. Forty years after witnessing their first collective rebellion, inhabitants welcomed one of the region's largest gatherings of activists in 10 years: the first edition of the Forum social Bas-du-Fleuve. By the end of the event, enthusiasm was patent.

In January 2011, a thousand participants gathered in Séné, a small village in the region of Brittany in France for the seventh edition of the local social forum FS 56. For two and a half days, participants attended conferences on three main themes: environment, food and labor conditions. They attended participative workshops as well as artistic performances, including plays and concerts. Lunch and dinner consisted of free home-made food served in a central room where participants had an opportunity to meet, discuss and visit the numerous stands presenting the various organizations involved in the social forum process. As for other editions, it was deemed successful by the few local media that did cover it.

Thousands of local social forums (LSF) like these are taking place all over the world each year. Few media report these events, even locally. Local social forums exist as "hidden collective actions" in the sense that while they do take place, they do not really exist publicly, or they receive very little publicity. Though LSF are hidden and have little visibility, this does not mean they are not important. These gatherings are very intriguing for at least two main reasons: Quantitatively, in Europe, part of North America (the USA and the province of Quebec in Canada), Latin America, South-East Asia and, more recently, Africa and the Arab World, thousands of people and groups who are committed to the fight for "another world" have been involved in local social forums 
(http://www.forumsocialmundial.org.br/main.php?id_menu=12_1\&cd_language=1). But beyond the numbers, LSF are an expression of the transformation of the Global Justice Movement. Immediately following the World Social Forum process, initiated in 2001 in Porto Alegre, Brazil, LSF became local gatherings of activists who wanted to "change the world" for themselves and their community. They are self-organized by local social actors and have no connections to institutional agendas. As a result, LSF are the concrete translation of global social justice movements at the local scale, offering an accurate barometer of the shape of the movement on a territory.

Yet we know very little about this phenomenon of collective action, the existing literature focusing more on social forums at the world or regional scale (della Porta and Tarrow, 2005; della Porta et al., 2006; Smith, Byrd, Reese and Smythe, 2012; Pleyers, 2010; Beaudet, Canet and Massicotte, 2010; Gautney, 2010). Subsequent editions of the World Social Forum (WSF) have been studied extensively since the first event took place in Porto Alegre in 2001, and we are very much aware of who was in attendance, how it was organized and what the underlying processes were. The same is true for the European Social Forum (ESF), at least for the first four editions held in Florence in 2002, Paris in 2003, London in 2004 and Athens in 2006 (della Porta ed., 2009; Sommier, Fillieule and Agrikoliansky, dir., 2008). In contrast, very few studies exist on local experiences (except for the US social forums) (Smith and Juris, 2008; Karides et al., 2010). In this respect, it is as if local social forums are understood mainly as a "natural" or non-problematic variation of larger events.

In this article, we wish to explore this presupposition: beyond the label "social forums," what do the practices of LSF specifically entail?

Existing literature on social forums at various scales (except at the world scale) offers some empirical evidence of the specifics of place-based forums, focusing more on their uniqueness than on their commonalities. Pleyers (2007: 131) mentions that LSF are built differently in each city, depending on the types of groups that are active in the localities, the connections among them, the affinities of local activists, etc. Canet (2008) shows that the Global Justice Movement is more diverse than generally believed, and he demonstrates how some regional/continental sensitivities 
appear in the themes addressed in the forums as well as in the forms of mobilization. In particular, he notes strong differences between ESF and ASF events. In 2011, we could probably add the Maghreb social forum as a contrasting example. Studies of local social forums provide an even clearer illustration. In Sweden, for example, local forums have been organized in seven different towns since 2002. They sometimes referred to themselves as "social forums" and other times as "socialist forums" due to a mix of factors, from the presence of certain actors and the absence of others, to the local political context or naming process (Nordvall 2009, 442). In their work, Larmer, Dwyer and Zeilig (2009) show how national, regional or continental forums in Africa (which have existed since 2002) have proposed a local re-appropriation of the forms and contents of the World Social Forum to make it more relevant to the social and political dynamics of Africa and closer to nation-state alternatives. Karides et al. (2010) demonstrate convincingly how the success of the USSF is in large part due to the involvement of the sector of grassroots organizations, especially in historically marginalized communities (p.9). These examples clearly illustrate how it is impossible to suppose that the label or name "social forum" describes specific forms or even content. The simple question "What are social forums?" appears to depends strongly on geography, that is, the place and scale of the forum.

To deepen our knowledge and understanding of the social forum process, we propose a comparison of eight cases situated in two very distinct societies, that is, Quebec and France. We argue that despite strong structural factors that have led to highly diverse situations and few points in common for LSF, at a certain general level, strong regularities do exist among cases. Local social forums function as a label in the sense that intentionality is shared by organizers (they have the same kind of expectation of what the format of the event and the process should be); the mode of operation of the LSF process and event belong to the same political culture and translate into the same practices; and the output of these gatherings are similar in terms of solidarity-building. Following the "soft" definition of repertoire (Fillieule, 2010), we show that despite strong national differences, a highly decentralized process and the strong autonomy of local actors, local social forums share certain structural characteristics. Furthermore, the name "social forum" is associated with ways of doing things that limit the variety of local social forums initiatives. 


\section{Methodology}

Our study is based on an analysis of eight local social forums. Four of the forums took place Quebec (Canada): Forum social Bas-du-Fleuve, Forum social Lanaudière, Forum social de Laval and Forum social du Saguenay-Lac-St-Jean. Four of them took place in France: Forum social du Morbihan (FS 56), Forum social en Forez, Forum social d'Ivry, and Forum social mondial en Provence (FSMP). As Snyder (2001) has underlined, comparing subnational units better equips us to handle the spatially uneven nature of social processes (p.94). In our study, we consider the LSF as the unit of analysis. In each society, we documented both the process that leads to the event and the event itself. We attended all events, carried out direct observations (in Quebec, with the help of two research assistants), made audio recordings of most of the workshops and gathered information regarding attendance, the number of workshops, the format of workshops and other activities (conferences and artistic performances). We also analyzed the physical attributes of the sites where the events took place. When possible, we led a workshop with participants during the event on the following theme: A Local Social Forum in X: What For? In Quebec, we were able to do this for each forum. The number of participants in our focus groups varied greatly, from 5 to 25 . In each case, we conducted the workshop with certain visual supports (photographs, statements, definitions) and asked the participants to react to these. Before and after the event, we conducted individual and group interviews with the organizing committee of the LSF, requested the minutes of each preparatory meeting for the event and analyzed what was written by the local media. Finally, we carried out extensive research on the local history of activism.

This multi-approach methodology, combining direct observation, focus groups, interviews and documentary analysis, has produced very rich data for each case. The primary aim of our study was not to select cases that were necessarily representative of LSF, nor was it to be exhaustive (even if in Quebec, this was probably the case). Rather, we chose to document a certain number of cases as thoroughly as possible in order to understand how activists in different local contexts make use of "social forums" and how they make them work.

Most of the LSF in Quebec took place in 2009, 2010 or 2011, while in France they took place in 2010 or 2011. Our selection of cases was based on two distinct strategies. In Quebec, we covered seven LSF organized on the territory (that is, all but one), and we selected the four most relevant 
for the purposes of this paper. These four cases best illustrate our argument; the addition of the remaining three would not have changed our analysis. For France, our selection was done on the basis of feasibility. More than $70 \mathrm{LSF}$ are organized on the territory each year, far too much for the type of qualitative analysis we are conducting. In the end, the eight cases we selected represent very diverse experiences and practices of the LSF, in terms of localization on the territory, the number of editions (from one to five), the dynamics of global justice forces in each society, and its history.

In the next section of this paper, we show that two trends compel us to focus primarily on the differences among the cases: first, Quebec LSF and French LSF have strong national specificities ${ }^{1}$; second, the conditions of emergence of LSF are very undetermined.

\section{Section 1 - Why the LSF Label Might Be a Misnomer}

Our eight cases, which are situated in two very distinct contexts, present strong differences that are connected to their national belonging. In the French cases, local social forum events are strongly related to the association ATTAC (Wintrebert, 2007) and its regional/local collectives. Thus, the presence/absence of ATTAC is certainly a determining factor in understanding most of the LSF experiences and initiatives on French territory, the coalitions of actors that are present or absent from LSF initiatives and the global dynamics among actors. ATTAC-France is a highly centralized structure - even if local particularities do exist (Ancelovici, 2002) - and the main function of its headquarters is to structure the actions of local collectives. Three periods can be distinguished in the relationships of the national association ATTAC-France with LSF initiatives. Between 2001 (first WSF) and 2003 (European Social Forum in Paris-St-Denis), local social forums were not encouraged at all by ATTAC-France and were not even recognized as a relevant experience (interviews, LSF organizers, FSI, Dakar, 2010). After 2004, ATTAC-France had more tolerance

\footnotetext{
1 Although Quebec is not a country but rather a province in a federal state, it could be considered analytically as a society, distinct from the rest of Canada in terms of its citizenship regime (Jenson, 1998). The two cases are not strictly equivalent, but this comparison has proven useful in the social sciences, given the amount of work published in very diverse subfields (Revillard, 2008; Dupuis-Déry, 2009; Bidard, Bourdon and Charbonneau, 2011; Vatz Laaroussi, 2001).
} 
for LSF, and some local collectives began to initiate certain processes, as illustrated by the LSF repertoire in France (http://openfsm.net/projects/facili-tation-de-fsl/annuaire-des-fsl). After 2008, an informal network operated by ATTAC leaders, the Réseau de facilitation des FSL, tried to foster LSF initiatives (http://openfsm.net/projects/facili-tation-de-fsl/project-home). Yet LSF in France are not solely an "ATTAC affair." For instance, no ATTAC members are involved in one of the cases we are considering (FSMP).

In Quebec, the national history of LSF is very different. The emergence of LSF is linked to two very diverse origins. At the outset, local initiatives were put forward by individuals who had participated in the WSF in 2001 or 2002 and decided to try something locally. They were like pioneers in a new field of action. This story begins in the Quebec City region. The inaugural event of the Forum social régional de Québec Chaudière-Appalaches took place in September 2002 and led to the founding of a permanent network, which is still in operation today. Also in 2002, youths of the Estrie region organized the FS de la jeunesse estrienne (a second edition was held in 2005). These first two initiatives used the social forum "label" and were inspired in large part by their participation in the WSF in 2001. However, their operating methods were quite distinct from the Porto Alegre Charter in that the event was structured as a deliberative process with the objective of producing a common declaration. Lastly, the LSF of the Outaouais region (2003) is a part of this history of people pioneering the social forum processes at different scales and trying to push similar local initiatives. The second turning point in the history of the LSF in Quebec is linked with the Quebec social forum (QSF) initiative (see Dufour and Conway, 2010 for a complete history of the QSF process; Beaudet, 2010). The chaotic trajectory of the QSF process from 2002 to 2006 generated specific learning opportunities for the activists involved in it. The QSF event in 2007 represents the point where a significant number of non-Montreal leaders learned about social forums for the first time. It also represented the place where activists from the various regions of Quebec received concrete incentives from the QSF process to elaborate social forums in their own areas, including financial incentives. This is the case for most of LSF that were held after 2007 in the regions, and it is the case for all LSF considered here.

Looking at the big picture, we note that the emergence of LSF in the two societies have nothing in common, and the contexts in which LSF initiatives were put into place are completely 
different. Moreover, empirically we found societal characteristics that distinguish the French and Quebec LSF experiences and reinforce the argument developed in the literature to the effect that regional or local social forums are colored by local characteristics.

For example, in our eight cases, a strong national difference exists in terms of the type of collective actors involved: in Quebec, community groups (mainly defenders of collective rights), unions and youth organizations were at the forefront of the experiences; in France, aside from ATTAC, we encounter solidarity associations, immigration networks and extreme-left networks. Overall, interest in LSF in France is much stronger among baby boomers than among teenagers or even young adults (with some exceptions), while in Quebec the intergenerational aspect of processes and events are very present. Often, young people provided the spark behind the LSF initiatives. Also, the building processes underlying LSF are very different in terms of their degree of inclusion. The organizational process appears much more open in the Quebec context. In most LSF in Quebec, the formal organization of LSF initiatives was as follows: a sovereign general assembly where everybody was allowed to participate in the debates (rules were adopted in certain cases to manage the right to vote for non-affiliated individuals versus group representatives, but in other cases, the rule was simply one vote per person), and a coordination committee with subcommittees was in charge of the day-to-day work. The planning of the event was based on the World Social Forum format: self-organization. In other words, groups and/or individuals had to suggest and lead conferences and workshops. In most of the cases, one or two people were paid to coordinate the process, and other highly involved members often exercised their role within committees as part of their job. In two cases, the legal status of LSF was formally recognized (non-profit organizations or associations of individuals, which are the two possible categories under Quebec law). In three other cases, an informal collective managed the process, but they were always closely connected to an organization or networks of organizations. This access to important material resources is tied to the involvement of unions as well as with the public financing of social groups, which is very specific in Quebec (White, 2004; Laforest, 2012). Interestingly, this semi-institutionalization of the organizational process (because people were officially in charge of the process and paid for their work) goes hand-in-hand with a very open mode of operation. In France, in all of the cases considered, the organizers were volunteers. As a consequence, FSL processes and events were very dependent upon external resources (public authorities and municipalities that were willing to 
support them). The organizational processes were much less open than in the Quebec cases. In all but one, members of the organization committee decided on the program content and who was invited to conferences and workshops.

Lastly, LSF in France are usually much more closely connected to the global framework (e.g., the fight against neoliberal policies and globalization and the strong presence of political analysis of contexts at the conferences and workshops we attended). In Quebec, in contrast, local problems take center stage. Sometimes, the connections with more general political dimensions and contexts are only built during the event and not even mentioned in the program. In other words, the political analysis is more the result of the event than its point of departure. Of course, there are exceptions. In Quebec as well, the potential for collective learning was higher because events were viewed as participative processes that had the potential to produce concrete local alternatives in the future.

Beyond national differences, we must highlight two characteristics of LSF emergence that might create a very undetermined context, thereby reinforcing the probability of high varieties among cases. First, there is no hierarchy between the international committee of the WSF and LSF initiatives. If someone wants to initiate and organize a LSF somewhere on the planet, it can be done, and nobody will verify the "authenticity" of the process and deliver the label; you can use it if you want to (conference speaker Chico Whitaker, member of the International Committee, World Social Forum, Dakar, 2010). In this highly decentralized context, the question of practices is even more interesting: with no obligation, legal framework or any constraining rules, what do people do with social forums at the local level? At first glance we found a great disinclination of the LSF context: local leaders could decide to organize an LSF once and then stop; they could decide not to organize one at all; or they could organize them for years and then stop. In this context, it would be reasonable to expect that LSF should be connected mainly with local affairs and that local factors (e.g., political context, local activist history) would play the main role in explaining the differences among cases. 
In the following sections of this paper, we argue that LSF are much more than very different events sharing the same name; they are a new item in the toolbox that collective actors can mobilize at some point, both as a tactical and cultural repertoire of action.

\section{Section 2 - LSF as a Tactical and Cultural Repertoire}

Following Fillieule (2008: 11), we adopt a "soft" definition of tactical repertoire, as a distinct universe of practices, multiple but not without limitation, codified and routinized, transformable, historically constituted and culturally delineated, but always in motion. As Siméant has demonstrated in the context of hunger strikes, when such an action begins, a specific process is beginning with its own rules, its own temporality and its own logic, "giving a family resemblance to movements initiated by very different actors" (Siméant, 2009: 9) (author's translation). This is exactly what happened with LSF processes.

Tilly first developed the concept of the collective action repertoire in the 1980s (Tilly, 1977; Tilly and Tilly, 1981; Tilly, 1984). The concept has undergone several formulations since that time, but when Charles Tilly reworked it in 2008, he drew a distinction between protest repertoires and tactical repertoires (consisting of a set of performances). Each protest repertoire is closely linked to a certain period of history. Thus, the pre-modern repertoire of protest in Europe was linked to the form of the pre-modern state (mainly local and non-centralized), while the modern protest repertoire was linked to the modern form of the State (organized at the national level and much more centralized). A protest repertoire of actions contains several tactical repertoires that coexist. Inside tactical repertoires, actors make strategic choices among different performances. Each organization has some preferences for one performance or another, depending also on the political context in which claims are formulated. In the next section of this article, we consider LSF as a tactical (and cultural) repertoire, imposing $a$ universe of constraints upon actors that choose this specific set of performances, which are relatively standardized. Activists who are involved have a shared consciousness of what the performances should look like in terms of the nature of the interactions, what is expected and what is not expected, and how it should operate. 
However, beyond means of actions, the cultural dimension of tactical repertoires should be taken into account (Diani, 1992: 11) because social movement actors are involved in political and/or cultural conflicts. For Taylor, Rupp and Gamson (2004), the meaning people give to their actions plays a major role in whether or not they make use of a tactical repertoire. Fillieule (2010) urges analysts of social movements not to detach the observation of modes of actions from the cultural meanings that are attached to them by those who use them or by the targeted populations. In this perspective, a mode of action (or a tactical repertoire) always carries some meaning, which varies depending on the actors that make use of it and the context in which it is expressed (Fillieule, 2010: 98). Following this line of inquiry (Steinberg, 1999: 780; Offerlé, 2008; Péchu, 2006; Siméant, 2009), we maintain and demonstrate that LSF consist of tactical and cultural repertoires of action. A comparison of our eight cases suggests that their emergence processes, the way in which participants made use of the event and the main results they produced, shared strong similarities.

First, LSF do have some crucial points in common: they are planned to bring together people belonging to a territory and to create bridges between them. LSF are also based on the shared willingness to "do things differently" (e.g., searching for alternative ways of acting in their respective domains but also experiencing alternative ways of being together). So, actors involved in the organization of LSF know in advance what it should be or look like, and they share an intentionality. Second, LSF offer a practical framework: the process and the events go hand in hand with certain types of debates and certain types of practices (and not with others).

\section{Intentionality}

The intentionality of core organizers at the beginning of the process is very clear: they choose to organize an LSF to bring different people together and create a place where then can meet, talk and learn from each other. In the eight cases considered, the explicit aim of each forum was for participants to work together to change, transform or solve problems and to find alternatives in the local area.

LSF are planned as "a space of meetings for groups and/or individuals"; "a space of potential convergences among groups"; "a space of learning from the experiences of others"; and "a space 
of citizens' participation." (interviews with LSF coordinators) (author's translation) All organizing committees hope that LSF will contribute to the social transformation or social change of their region. The slogans adopted to promote the events are also very clear on this issue: "To open new paths" (Lac-Saint-Jean); "Towards a social warming (Bas-du-Fleuve); "For a more human tomorrow" (Laval); "Another world is possible; work together to reach it" (Ivry); "Learn, think and act for another world" (Morbihan); "Imagine, share, resist, exchange: Solidarity in all its states" (Forez).

These aims are very congruent with the way activists and leaders define WSF. The first article of the WSF Charter of principles states:

The World Social Forum is an open meeting place for reflective thinking, democratic debate of ideas, formulation of proposals, free exchange of experiences and interlinking for effective action, by groups and movements of civil society that are opposed to neoliberalism and to domination of the world by capital and any form of imperialism, and are committed to building a planetary society directed towards fruitful relationships among Humankind and between it and the Earth.

Clearly, LSF organizers situate their forums along the lines of the WSF, at least in their discourse.

Interestingly, in all cases, activists involved in the organization process referred to other social forums they had heard about or in which they were involved, and the fact that they had decided to do something locally back home. But it is important to note that the pre-practices of social forums are not a necessary condition for having a forum take place somewhere; the theoretical knowledge of it is sufficient for people to initiate a process, even if it is very vague. In addition, the referent social forum could be local (or national) and not just at the World or European scale. Therefore, the important point is not so much the notoriety of a forum than the knowledge of an experience or its existence. As one of our key sources from FS Bas-Saint-Laurent has stated, "It is part of our vocabulary now; we all have heard of social forums." (author's translation) So, a common image of social forums definitely exists. People who decide to organize a forum know what it should look like, and they know that it exists as a tool that can be activated and mobilized. What makes social forums local is the emphasis of forum leaders on the territory over which they have control. For 
example, sometimes it is only the town in which the forum takes place. This idea is crucial in all of the cases we documented: LSF were seen as a place where participants could create certain levers of actions together at the local level. Not only do LSF share an image, but they also offer a framework of actions, during the emergence process as well as during the event.

\section{A Cultural and Tactical Framework of Action}

The organizing committees in all eight cases declared that they would follow the WSF Charter of Principles. Some LSF formally adopted their own local version of the WSF principles, while others simply applied its most important rules, namely, that social forums are open meeting spaces (art. 1), that nobody is entitled to speak on its behalf (art.6), that political parties are excluded from the forum spaces (art. 8) and that social forums value diversity and plurality (art. 9). These principles restricted the practices of LSF, mainly because they caused disagreement among organizers and activists.

The minutes of the meetings show that hours were spent discussing some specific issues (which, in the majority of cases, were the same). As mentioned earlier, the formats of the events were very diverse, but there were underlying similarities present in all cases. The main points of disagreement among activists included the following: the format of the proposed activities and their respective weight (whether to hold conferences with experts, specialists, intellectuals and professionals, versus more participative workshops and artistic performances), the location of the forum, the management of its finances (whether to charge entrance fees and the question of sponsors and grants), the presence of political parties or of private actors and the individuals (officials) invited to attend the opening event and the follow-up of the event. This is not happenstance: social forums are born outside of (and sometimes against) party politics and representative democracy in order to give a voice to social movements, their opposition to economic and financial globalization, and their translation into political systems (Pleyers, 2011). So, LSF, as tactical and cultural repertoires of action appropriated by local actors, have to deal with this genealogy and the same types of issues. Organizing an LSF involves specific steps and specific decisions that reinforce the common points of LSF despite their variations. 
But even if a consensus existed at the level of principle, disagreements still arose during the event. For example, in a majority of the cases analyzed, multi-activists who belonged to a political party and to an organization felt uncomfortable with the rule that excluded political parties. One of the participants of the Forum social Lanaudière (Quebec) explained, "At the end of the forum, during the plenary session, I felt very frustrated that the federal Member of Parliament was invited to speak and use the forum for the purposes of self-promotion, while I was not allowed, as a participant, to speak on behalf of my party, Québec Solidaire." (author's translation)

This tension reflects the dynamics of the relationships between the social movement field and left politics in the two societies. We know that in France, several ATTAC activists are also involved with the Socialist Party or Les Verts (Waters, 2006), while in Quebec, many activists involved in LSF are, at the same time, activists within community groups and activists within the new left party, Québec Solidaire (Dufour, 2009).

Another clear illustration of this point is the question of the "status" of social forums, as a space that does not have the power of an entity (no one is allowed to speak on behalf of the forum, and no statement can be made on behalf of the forum). However, adhering to this rule during the event can be dangerous. For example, during the concluding plenary session of the Forum social Bas-du-Fleuve (Quebec), some participants expressed the desire to end with something concrete and collective. The assembly of 400 participants who were gathered in the church asked for a statement by the forum. Several organizers explained that it was not possible, because the forum was only a space. "This is not the purpose of a forum; it is not its role. If we did that, it would not be a forum but something else." (Closing conference, coordinator, Esprit-Saint, 2011) (author's translation)

The same kind of issue arose during the Forum social de Laval (Quebec), during the FSMP and during the FS 56 (France). Each time, the organizers explained their position: a social forum is not an organization that is able to make decisions. Rather, it is an opportunity for debate and awareness. Organizations present during a forum can take away certain ideas and transform them into actions. Also, some alternatives were suggested to satisfy the desire of the participants to end with 
"something concrete and not just speeches" (interview, participant, FS Morbihan): to write and publish a synopsis of the forum with proposals for future actions to be initiated or followed by the community or to mandate a committee outside the forum to write a manifesto.

As we can see, activists who contributed to the emergence of a local forum had a very strong opinion about what a forum was and what it was not, and the occasion of the forum was a learning opportunity for participants. Our focus groups at the events were also very struck by the surprise of first-time participants concerning the notion that "we are not an entity or a body and we will not make decisions." In contrast, veteran social forum participants were much more comfortable with this rule, and some of them defended it. For the majority of organizers, the absence of a representative body is an integral part of the nature and success of LSF.

To deal with these recurring nodes, organizing committees used consensus-building as their dominant strategy, and it is a common point in all the cases studied. In the interviews conducted, all key actors insisted that consensus-building was the most important element in explaining the success of the process, its particularity and its identity. For example, the coordinator of the Forum social Ivry (France) stated, "Without consensus, we would not have been able to sustain our activities for such a long time, and we would not have grown in this way, with more and more associations asking to join us. It is a question of spirit. We have adopted the spirit of the WSF, and at the heart is consensus-building." (author's translation)

In Quebec, the main coordinator of Forum social de Laval said, "It works very well. Of 11 people, only one or two were more reluctant concerning some decisions. But after discussing it we were all able to agree. That is very important in a forum; if not, it will not work and it will not be a forum, right?" (author's translation)

In the interviews, consensus was presented as an essential, fundamental characteristic of the forum, distinguishing it from other places where people are involved. They are extremely attached to it as a value and a principle upon which actions are based. From our analysis, it is also clear that consensus-building was a concrete practice they tried to apply. 
The reasons underlying this strong characteristic are very complex and interrelated. They involve the willingness of activists to value, in theory and in practice, a counter-political culture, offering an alternative to the majority rule. Consensus-building is also seen as a way of getting to know each other better and learning from exchanges, even if it is generally considered to be inefficient in terms of time spent versus the nature of the decisions taken.

A clear illustration of this was provided by the FS 56. In the minutes of the 15 meetings that preceded the $2011 \mathrm{LSF}$, we note that the principle of action "search for consensus" was re-affirmed, and members present were reminded of this each time a disagreement arose. Sometimes, several meetings were necessary before a decision could be taken. It is important to emphasize that organizing committees tried to reach a consensus before a decision was taken, but this did not mean that such consensus was reached without power struggles or tension.

We observe from the cases studied that LSF were originally initiated to "change" or "transform" local situations or local ways of doing things. Also, LSF were thought of as a way of doing things together, but in a different way than what had been done previously in the community. A minimum level of rules was adopted in the consensus-building process to provide certain guidelines for participation and the decision-making process that define the boundaries of a specific political culture. The people who were involved in the elaboration process spent a large amount of their time trying to balance the theories and practices of the social forum process, asking how horizontal, how inclusive and how efficient it was in practice. The same kind of introspection is present in social forums organized at other scales (see for example De Angelis, 2004; Sen, Anand, Escobar and Waterman, 2004; Smith and Juris, 2008; Karides et al., 2010). Beyond their differences, LSF belong to the same kind or family of events. In the last section of this article, we demonstrate how LSF are producers of solidarities, during the building process as well as during the event.

\section{Section 3 - LSF as Producers of Solidarities}

The LSF emergence processes show that people have learned a great deal from each other and have developed a habit of working together over quite a long period of time (ranging from six months to two years, with at least one meeting per month). This is true at the level of individuals as well as at the level of organizations. Since organizations are involved in multiple fields of action 
(housing, immigration, poverty, etc.), these strong ties that have been built have an impact on the future of their potential collaboration. In collective interviews, activists underlined the richness of the ties developed and how it has affected the work of their organizations afterward.

For example, one of the Forum social Forez (France) members stated, "I am very active in the association Amnesty International. They are not used to thinking about globalization and having a political position on neoliberalism. Therefore, it is quite a stretch from alterglobalization. However, since I am involved in the local social forum process, I was able to bring these issues to their attention. I asked a lot of questions, I knew people, I knew who did what, and I was able to work better with them. I think it has enriched my work, and it has also enriched the work of my association." (author's translation)

For the person in charge of the mobilization committee, working to create the Forum social Basdu-Fleuve was "a way of working for the social development of the region (her job at the Rimouski town) and establishing connections between all the people working in this field who did not know each other." (author's translation) In the cases where subsequent editions of LSF were held, we note that all organizations involved at the outset continued to be part of the process, reinforcing the argument that solidarities have been built by the process of emergence itself. Two other examples can be provided here as illustrations. In the FS Ivry process, each year of its existence corresponds to an extension of the networks involved in the forum, as well as the networks outside of it. For example, since the beginning in 2004 , they have progressively included immigration groups, which allowed all group members to develop new links with groups abroad, in their home country. Locally and globally, solidarity ties were extended. Between the first and second editions of the FS Forez, solidarity ties were much stronger among member groups and individuals; they knew how to work together very well, and they also shared more analyses. Here, it was not the scope of the actions that grew, but the degree of convergence among groups.

At a certain level of generality, we can say that LSF are "machines that produce solidarities," and these machines come with a set of instructions to follow: specific steps for development, specific debates and specific ways of doing politics. Beyond the process, the event itself creates solidarities among participants. People involved in a collective action are building social relationships of 
a certain type, producing effects on individuals and groups and on the way the event is taking place (Fillieule, 2010).

LSF are undoubtedly an individual learning experience, independent of the format. Participants learn something about the subject they have selected. In the case of conferences given by experts, it is more of a passive learning process; in case of participative workshops, it is more active. In all focus groups conducted, participants emphasized the high level of knowledge and understanding generated by the event. "In two days, I have learned so much! Of course, I have to take some time to digest it all, but I am certainly a different person now than two days ago, certainly." (participant, FS Saguenay-Lac-St-Jean) (author's translation)

In most of the cases, LSF are not only designed and thought of by organizers as a "space of meeting, exchanges and transformations"; they are also used as such by participants to differing degrees. While participants describe all LSF as providing very rich personal experiences, we note that the time schedule of the event, the physical characteristics of the place where the event takes place, the physical characteristics of the rooms where workshops and activities are held (Lorenzo and Martinez, 2001) and the preferred method of workshop participation have an influence on the level of learning reached. Two types of forums can be distinguished by the degree of conviviality offered. The first type is very similar to an academic congress: there is not much time between sessions, no specific place to eat, few artistic events scheduled in the evenings, and the room setups do not favor discussions and exchanges. These events generally take place in the buildings of a university campus, which offer little in the way of conviviality and minimal opportunity for exchanges and meetings among participants. The other type of forum is at the opposite end of the spectrum: the event is organized in a small town, with rooms available on site that are all within walking distance. They have a specific place designated for people to meet outside the activities, and participants are able to dine together, sampling local food. Participants feel more like guests than delegates at a congress. People are very friendly, there is a high degree of positive energy, and the level of individual learning is much higher. Of course, several empirical situations fall between these two types. For example, the FS Lanaudière was held in a college, but much effort was put into the welcoming of participants with local foods and common meals. 
Interestingly, we note that to become a collective learning experience (and not only an individual one), LSF must be organized in a specific manner. In particular, the presence or absence of discussions in plenary sessions and the presence or absence of transversal or convergent workshops are important moments in the collective building of solidarities. For example, in one of the forums studied (FS Bas-du-Fleuve), the format of each workshop was imposed by the coordination committee: they asked people who proposed an activity to follow strict rules, with three quarters of the time allotted for collective discussion and only one quarter of the time allotted to the moderator. They also suggested the use of participative strategies such as role-play or work within small groups. Furthermore, the content of discussions that took place in parallel workshops on the day of the forum was reported to all participants via written documents, posters and signs on site. Persons in charge of workshops strictly followed these guidelines, and participants were kept highly informed and very active during the event. When organizers structure the format of an LSF so that people can speak and think together, it generally works this way.

\section{Conclusion: LSF as a Tactical and Cultural Repertoire of Collective Action}

Why have activists decided to spend months or even years locally organizing social forums, which have been described by certain detractors as a party-like event intended solely for activists, consisting only of speeches, with no decisions and no results (Singleton, 2004)? Why do thousands of activists around the world choose to attend their local social forums, spending two or three days in rooms, sitting in uncomfortable chairs without even the travelling experiences offered by World Social Forums? They surely can't be accused of activist tourism.

In this article, we suggest and argue that the answer to this intriguing question lies in the functions of LSF at the local level. We have demonstrated that, at a certain general level, LSF initiatives operate as a cultural and tactical repertoire for social actors who mobilize the format and label of the social forum. 
A comparison of the eight cases of LSF in Quebec and in France demonstrates that beyond national differences and beyond the indeterminacy of LSF context, they can be analyzed as a tactical and cultural repertoire.

All cases are justified in terms of "working for social change (or social development)" and "searching for alternatives, together." The LSF building processes also follows central rules. Most LSF adopt a Charter of Principles at the beginning of the process or refer to existing Charters in their day-to-day operations. Without exception, they also follow the rule of consensus-building when making decisions, which is applied to certain recurring debates. Even if the various social forums do not arrive at the same decisions on these issues, the fact that we found common ground in the debates among the organizing committees shows that the format of the tactical repertoire (a social forum) acts as a set of constraints (and possibilities) for action. In this respect, social forums offer key guidelines for the actors involved. During the event, we also observed that certain constraints (and possibilities) were constant in our cases. For example, since an LSF is a space of dialogue as opposed to a decision-making body, this limits the type of output that is possible. However, it can also push for creative alternatives in terms of follow-ups to the LSF and successive collective actions on the territory. Finally, we have shown that LSF are efficient tools for individual and collective learning experiences as well as for building inter-individual and collective solidarities.

Baykan and Lelandais (2004) analyze an emerging social forum at the national level together with certain local initiatives and show how social forums bring together different political cultures, producing social changes through interaction. Smith and Juris (2008) and Karides et al. (2010) reached the same type of conclusion for the USSF. The International Council of the World Social Forum, which called for a US social forum in 2004, provided the first input. Then, US activists and leaders developed regional and local forums in order to prepare the initiative at the national scale. In the end, the USSF proposed a few new avenues for the world process, especially in terms of inclusion of a wide range of grassroots organizations and selffinancing. 
In the cases we have studied, it is difficult to reach the same conclusion. Social change is definitely one of the main goals of LSF organizers; however, the measure of the change actually achieved by the end of the process is beyond the scope of this paper, and further analyses will need to be done. What we have found is that the LSF experience brings about change for participants as well as for collective actors. Nevertheless, LSF are more than this: they offer a pragmatic and what is perceived as an efficient tool for local needs.

LSF are generally relatively distant from the State agenda and are self-convened by coalitions of social groups and/or individuals with varying degrees of formality. During the event, they usually propose a mix of festive, artistic and reflective actions. There are clear borders delineating who is in the process and event and who is not, and events generally take place in closed buildings (even if they are public), with the exception of artistic performances that take place in the streets. Overall, LSF are not radically transforming the forms of protest in the societies considered, but they do offer an answer to the perceived lack of dialogue among different sectors of struggles: the need for local social actors to collectively appropriate the complex dynamics of economic globalization and its impacts, and the need to search for new opportunities for change in situations that are traditionally closed to change. Overall, they are certainly redefining the boundaries of social resistance. 


\section{Bibliography}

Ancelovici, Marcos. 2002. "Organizing against Globalization: the case of ATTAC in France", Politics and Society, 30, 3: 427-463.

Baykan, Baris Gencer and Gülcin Erdi Lelandais. 2004. "Cross-readings of the anti-globalisation movement in Turkey and beyond. Political culture in the making », International Social Sciences Journal, 56, 182 (December) : 519-528.

Beaudet, Pierre, Canet Raphaël et Massicotte, Marie-Josée. 2010. L'altermondialisme. Forums sociaux, résistances et nouvelle culture politique. Montréal : Écosociété.

Beaudet, Pierre. 2010. « Asterix On The St Lawrence » Jai Sen, Peter Waiterman, dir. 2009. World Social Forum : challenging empires. Montreal: Black Rose Books, p. 332-42.

Bidart, Claire, Bourdon Sylvain, Charbonneau Johanne. 2011. "Le rapport au travail des jeunes au Québec et en France : mise en perspective longitudinale », in Les catégories sociales et leurs frontières, Alain Degenne, Catherine Marry, et Stéphane Moulin (Ed.), pp. 85-110 - http://halshs.archives-ouvertes.fr/halshs-00660052.

Canet, Raphaêl. 2008. "L'intelligence en essaim. Stratégie d'internationalisation des forums sociaux et régionalisation de la contestation mondiale », Culture et conflits, 70, été : 33-56.

Costanza-Chock, Sasha (2003), "Mapping the Repertoire of Electronic Contention," in Andrew Opel and Donnalyn Pompper (eds.), Representing Resistance: Media, Civil Disobedience and the Global Justice Movement. NJ: Greenwood.

De Angelis, Massimo. 2004. «Opposing fetishism by reclaiming our powers : The Social Forum movement, capitalist markets and the politics of alternatives », International Social Science Journal, 56, $182: 591-604$.

della Porta, Donatella, ed. 2009. Another Europe. Conceptions and practices of democracy in the European Social Forums, London : Routledge.

della Porta, D. et S. Tarrow, dir. 2005. Transnational Protest and Global Activism. Lanham, Rowman \& Littlefield Publishers.

della Porta, D., M. Andretta, L. Mosca, H. Riter. 2006. Globalization From Below. Transnational Activists and Protest Networks, Minneapolis : University of Minnesota Press.

Diani, Mario. 1992. "Analysing Social Movement Networks", Studing Collective Action, in Mari Diani and R. Eyerman (eds.), London: Sage, pp. 107-135.

Dufour, Pascale and Janet Conway. 2010. «Emerging Visions of Another World? Contestation and Collaboration at the Quebec Social Forum », Journal of World System Research, vol.26, 1: 2947.

Dufour, Pascale. 2009. "From Protest to Partisan Politics : When and How Collective Actors Cross the Line ? Sociological Perspective on Québec Solidaire", Canadian Journal of Sociology, Vol. 34, No. $1: 53-78$.

Dupuis-Déry, Francis. 2009. «L'anarchisme face au féminisme. Comparaison France-Québec », dans Le sexe du militantisme, Olivier Fillieule et Patricia Roux, Paris : Presses de sciences po, pp. 187-204. 
Fillieule Olivier, 2010. «Tombeau pour Charles Tilly. Répertoires, performances et stratégies d'action, in Éric Agrikoliansky et al., Penser les mouvements sociaux, Paris : La Découverte, pp. 77-99.

Fougier, Eddy. 2007. «L'extrême gauche et les mouvements altermondialistes », dans D. Reynié (dir.), L'Extrême gauche, moribonde ou renaissante ?, Paris, PUF, 2007.

Fox Piven, Frances Fox and Cloward, Richard A. 2000. "Power Repertoires and Globalization", Politics \& Society, Vol. 28, No.3, 413-430.

Gagnon, Alain, dir. 1981. Les Opérations Dignité: naissance d'un mouvement social dans l'est du Québec, Montréal: Léméac, GRIDEQ et Carleton University Bookstore.

Gautney, Heather. 2010. Iprotest and organization in the Alternative Globalization Era. NGOs, Social Movements, and Political Parties, New-York : Palgrave MacMillan.

Imig, Doug and Tarrow Sidney (1999), "Contentious Europeans: Is There a European Repertoire of Collective Action?", Conference on Europeanized Politics Nuffield College, Oxford, June 1719, Accessed at http://www.ciaonet.org/wps/imd03/

Jenson, Jane. 1998. « Les réformes des services de garde pour jeunes enfants en France et au Québec : une analyse historico-institutionnaliste », Politique et Sociétés, 17, 1-2 : ????.

Sommier, Isabelle, Fillieule, Olivier, Agrikoliansky, Éric, dir. 2008. Généalogie des mouvements altermondialistes en Europe. Une perspective comparée, Aix : Karthala.

Karides, Marina and al. 2010. The united States Social Forum : perspectives of a movement. Chicago : Changemaker Publications.

Kipfer, Stefan. 2009. «Trackling Urban Apartheid : Report from the Social Forum or Popular Neighbourhood in Paris », International Journal of Urban and Regional Research 33, 4 : 10581066.

Laforest, Rachel. 2012. Voluntary Sector Organizations and the State. Building New Relations. Vancouver, UBC Press.

Larmer, Miles, Peter Dwyer and Leo Zeilig. 2009. « Southern African social movements at the 2007 Nairobi World Social Forum » Global Networks 9, 1 : 41-61.

Lorenzo, Ana Rosa and Martinez, Miguel. 2001. Asambleas y reuniones : Metodologías de autoorganización, Torrecedeira : Traficantes de Sueños.

Mueller, Carol. 1999. "Escape from the GDR, 1961-1989: Hybrid Exit Repertoires in a Disintegrating Leninist Regime”, American Journal of Sociology, Vol.105, No.3, 697-735.

Nordvall, Henrik. 2009. "Making Sense of the Social Forum. On the local Framing of a Fashionable Global Symbol », Journal of Contemporary Ethnography 38, 4 : 435-464.

Offerlé, Michel. 2008. «Retour critique sur les répertoires d'action collective $18^{\mathrm{e}}-21^{\mathrm{e}}$ siècle », Politix, 1, 81 : 181-202.

Péchu, Cécile. 2006. «Entre résistance et contestation. La genèse du squat comme mode d'action », Travaux de science politique de l'Université de Lausanne, 24 :3-51.

Pleyers, Geoffrey. 2007. Forums sociaux mondiaux et défis de l'altermondialisme. De Porto Alegre à Nairobi. Louvain-La-Neuve, Belgique : Éditions Bruylant-Academia s.a. 
Pleyers, Geoffrey. 2010. Alter-Globalization. Becoming Actors in the Global Age, Cambridge : Polity Press.

Revillard, Anne. 2008. "Quelle politique pour les femmes ? Une comparaison France-Québec", Revue internationale de politique comparée, 15, 4: 687-704.

Richard, Jean. 2007. Au pays des Sinagots. Éditions de la découvrance.

Rolfe, Brett (2005), "Building an Electronic Repertoire of Contention”, Social Movement Studies, Vol. 4, No. 1, 65-74.

Sen Jai, Anita Anand, Arturo Escobar and Peter Waterman. 2004. The World Social Forum : Challenging Empires. New Delhi : The Viveka Foundation.

Siméant, Joanna. 2009. La Grève de la faim. Paris : Presses de science po.

Singleton, Michael. 2004. «Le World Social Forum de Mumbaï : foire, foutoir ou foutaise ?», Revue du MAUSS, 24, 2 : 428-440.

Côté, Simon-Olivier. 2007. Le développement durable et la démocratie participative : une étude de cas du réseautage de la société civile au Saguenay-Lac-Saint-Jean. Mémoire de maîtrise en géographie, UQAM.

Smith, Jackie and Juris, Jeffrey. 2008. «We are the Ones We have been Waiting for »: The US Social Forum in Context», Mobilization. An International Quarterly, 13, 4 : 373-394.

Smith, Jackie, Byrd Scott, Reese, Ellen and Smythe Elizabeth. 2012. Handbook of World Social Forum Activism, Paradigm Publishers.

Snyder, Richard. 2001. "Scaling down: The subnational Comparative Method », Studies in Comparative Development, 36, 1 : 93-110.

Steinberg, Marc W. (1999), "The Talk and Back Talk of Collective Action: A Dialogic Analysis of Repertoires of Discourse among Nineteenth Century English Cotton Spinners", American Journal of Sociology, Vol. 105, No. 3, 736-780.

Tarrow, Sidney. 1998. Power in Movement. Cambridge : Cambridge University Press.

Taylor, Verta and Van Dyke Nella, (2004), "Get up, Stand up": Tactical Repertoires of Social Movements In David A. Snow, Sarah A. Soule, Hanspeter Kriesi (eds.), The Blackwell Companion to Social Movements, Blackwell Publishing, pp. 262-293.

Verta Taylor, Leila J. Rupp, and Joshua Gamson. 2004. "Performing Protest: Drag Shows as Tactical Repertoires of the Gay and Lesbian Movement." Research in Social Movements, Conflict and Change, 25: 105-137.

Tilly, Charles. 1977. "Getting It Together in Burgundy, 1675-1975”, Theory and Society 4: 479504.

Tilly, Charles. 1984. Les origins du repertoire de 1, action collective contemporaine en France et en Grande-Bretagne, Vingtième siècle. Revue d'histoire, 4: 89-108.

Tilly, Charles. 2008. Contentious Performances, NewYork : Cambridge University Press.

Tilly, Louise A. and Tilly, Charles. 1981. Class conflict and Collective Action, Beverly Hills: 1981.

Tilly, Charles. 1995. Contentious Politics in Great Britain, 1758-1834, Cambridge: Harvard 
University Press.

Van Laer, Jeroen and Van Aels, Peter (2009), "Cyber-protest and civil society: the Internet and action repertoires in social movements" In Yvonne Jewkes and Majid Yar (eds.), Handbook on Internet Crime, Willan Publishing, Accessed at http://www.m2p.be/publications/1260489691.pdf, 230-254.

Vatz Laaroussi, Michelle. 2001. Le familial au coeur de l'immigration. Les strategies de citoyenneté des familles immigrantes au Québec et en France. Paris: L'Harmattan.

Waters, Sarah. 2006. «A l'attac: globalization and ideological renewal of the French Left», Modern \& Contemporary France, 05, 14, 2 : 141-156.

White, Deena. 2004. The voluntary sector, community sector and social economy in Canada : Why one is not the other, in Annette Zimmer \& Christina Stecker, Strategy Mix for Nonprofit Organisations. Vehicles for social and labour market integration, London: Klewer/Plenum.

Wintrebert Raphaël. 2007. "Attac France et le mouvement altermondialiste », Courrier hebdomadaire du CRISP, 2007/33-34 n 1978-1979, p. 5-62. 